\author{
JAN SOCHOŃ \\ Uniwersytet Kardynała Stefana Wyszyńskiego \\ Wydział Filozofii Chrześcijańskiej
}

\title{
Porwanie do „trzeciego nieba”. Tomasz z Akwinu o doświadczeniu mistycznym
}

\author{
Unde qui plus habebit de caritate, \\ perfectius Deum videbit, et beatior erit. \\ Tomasz z Akwinu'
}

\section{Uwagi wprowadzające}

Kwestie związane z mistyką czy mistycyzmem mają długą historię i przynajmniej do XX wieku wiązały się nierozerwalnie z doświadczeniami ściśle religijnymi, w szerszym sensie z konfesyjnym stylem życia. Dzisiaj natomiast nabrały niesłychanie otwartego charakteru, rozszerzając swoje pole znaczeniowe na wszelkiego rodzaju przeżycia ekstatyczne, transgresyjne, mające świadczyć o umacnianiu się nowych form ponowoczesnej duchowości, będących alternatywą dla tradycyjnych religijności bądź chcących je dopełniać lub poszerzać. W każdym razie tradycje mistyczne nadal zachowują w kulturze trwałą pozycję i nie wypada ich zbywać żadnym lekceważącym gestem. Na ogół zresztą tego się nie robi, co skutkuje niebywale bogatą literaturą na ich temat ${ }^{2}$.

1 Thomae Aquinatis, Summa theologiae I, q. 12, a. 3. Podaję według tzw. edycji Leonina w wydaniu Mariettiego, Taurini-Romae 1952. Dalsze cytaty z tej krytycznej edycji.

2 Nie podaję szerszej literatury dotyczącej mistyki, gdyż interesuje mnie przede wszystkim myśl św. Tomasza z Akwinu. Niemniej jednak wskazuję na dokonania Bernarda McGinna, który ostatnimi czasy napisał całą serię dzieł poświęconych mistyce chrześcijańskiej, o wyjątkowej naukowej wartości. Zob. tegoż, Fundamenty mistyki. Obecność Boga. Historia mistyki zachodniochrześcijańskiej (do V wieku), tłum. T. Dekert, Kraków 2009; Mistycy wczesnochrześcijańscy. Wizje Boga u mistrzów duchowych, thum. E.E. Nowakowska, Kraków 2008; Mistyczna myśl Mistrza Eckharta, człowieka przed którym Bóg niczego nie skryt, tłum. S. Szymański, Kraków 2009. 
W historii interesującego mnie tutaj zagadnienia rolę nie do przecenienia odegrał św. Tomasz z Akwinu, którego życie i poglądy przywierają (w pewnych wymiarach) do współczesnej, bez wątpienia pozaliberalnej mentalności religijnej i naukowej, zwłaszcza tam, gdzie mówi się o działalności intelektu uprawianej w taki sposób, by mogła stanowić wyraz pobożności i miłości, jak też chęci przekazywania prawdy innym ludziom, oraz tam, gdzie porządek nadprzyrodzony nigdy nie stanowi (jak na przykład w przekazie Pascala) czegoś całkowicie oderwanego od podłoża mającego charakter przygodnościowo-zmysłowy.

\section{W świetle intuicji bytu}

Doktor Anielski jako człowiek spokojny i zrównoważony popadał w swego rodzaju naukową złość, kiedy stykał się z poglądami o manichejskim zabarwieniu bądź sugerującymi, że strona duchowa osoby ludzkiej nie musi w żadnym razie być przyporządkowana stronie cielesnej albo że szansa osiągnięcia zbawienia będzie możliwa tylko w naturze przypominającej naturę duchów czystych. Raczej podkreślał, że nawet najbardziej wysublimowane akty duchowe człowieka są powiązane z porządkiem cielesnym ${ }^{3}$, choć należy pamiętać, iż w stanie uszczęśliwiającym ludzkie poznanie będzie nieskończenie przewyższać to, jakim dysponujemy w doczesności. Czy sam jednak należał do osób, którym przysługiwałoby określenie „mistyk”, skoro właściwie nie wypowiadał się na temat osobistych doświadczeń w tym względzie, a przywołane słowo obrosło tak rozlicznymi semantycznymi rozrostami, że straciło właściwie rdzenny sens i trzeba się nim rozważnie posługiwać ${ }^{4}$ ?

Otóż, rzecz cała sprowadza się do zasadniczej konstatacji, że nie mamy powodu, by obiektywną bezosobowość narracji św. Tomasza odzierać z jej związków z prywatnym doświadczeniem autora. Te sfery są zawsze ze sobą spojone. Święty Tomasz wszak filozofował, mając na celu sprawy ściśle teologiczne. Był rdzennie teologiem, którego aktywność życiowa, dosłownie we

3 Według Tomasza tylko intelekt czynny przynależy człowiekowi z natury rzeczy, choć zawsze musi być pobudzany do działania przez dane zmysłowe. Bonawentura w powyższej kwestii inaczej rozkładał akcenty. Przekonywał mianowicie, że nie każde poznanie bierze się ze zmysłów. Znajomość pierwszych zasad, których wprawdzie nie moglibyśmy poznać, gdybyśmy nie mieli wrażeń zmysłowych, jest jednakowoż człowiekowi w pewien sposób wlana wraz ze światem umysłowym. Dusza bowiem musi znać Boga, samą siebie i to, co jest w niej, bez żadnego udziału zmysłów. Mamy więc tutaj do czynienia z pewnego rodzaju wrodzonością. Zob. tegoż: In Sententiarum, II, 39, 1, 2, c. Podaję za: S. Swieżawski, Dzieje europejskiej filozofii klasycznej, Warszawa-Wrocław 2000, s. $612-613$.

4 Sam termin ,mistyka” pojawił się dopiero w czasach nowożytnych, kiedy przymiotnik mystic (ang.), mistico (wł.) czy mystique (franc.) zaczął być używany jako rzeczownik, tak że pewnych ludzi nazywano „mistykami”, choć językowe próby ujęcia tego doświadczenia sięgają czasów greckich. 
wszystkich swoich wymiarach, zmierzała ku kontemplacji, ku duchowej jedni z Bogiem. W tym aspekcie nie jest on zbyt daleki od Augustyńskiego solilokwium i naprawdę pod osłoną łacińskiej składni zwierza się ze swoich najbardziej intymnych przeżyć. Étienne Gilson doprecyzował tę uwagę następującym komentarzem:

W Sumie teologii, z jej abstrakcyjną jasnością i bezosobową przejrzystością, skrystalizowało się w uchwytnej dla nas i w wiecznotrwałej postaci życie wewnętrzne św. Tomasza z Akwinu. [...] Rytm zdań i dźwięczność słów nie mącą ładu myśli; mimo to jednak każdy, kto ma trochę wrażliwości, wyczuje w tej miarowej kadencji zdań wzruszenie, niemal poezję ${ }^{5}$.

Powyższa obserwacja znajduje potwierdzenie w filozoficznym wymiarze systemu św. Tomasza. Jego metafizyczny zamysł zasadzał się przecież na oczywistości idei bytu, leżącego u podstaw wszelkiego rozumienia. Powiadał on wyraźnie: tym, co pojmuje intelekt jako najbardziej znane i do czego sprowadzają się wszystkie pojęcia, jest „byt”, gdyż każda natura jest istotowo bytem $^{6}$. Nie jest on wynikiem myślenia dyskursywnego, czymś wykoncypowanym; zrozumienie bytu (będacego) raczej poprzedza i stanowi podstawę wszelkiego zrozumienia i poznania jako warunek ich możliwości. Gdy się go nie rozumie, wówczas niczego właściwie nie sposób pojąć. Jak to się jednak dzieje, skoro rozumienie bytu poprzedza wszelkie myślenie i poznanie?

Ten fakt dokonuje się intuicyjnie i bezpośrednio, dlatego w poznaniu pierwszych pryncypiów żadnej pomyłki być nie może, ale tych bezpośrednio oczywistych zasad człowiek w ich niezawodności doświadcza pierwotnie w samym sobie, gdyż pewność co do samego siebie jest bodaj najbardziej niezawodna, o czym poświadczał już św. Augustyn, a w czasach nowożytnych Kartezjusz, czyniąc z owej niezaprzeczalnej pewności bazę swej rewolucyjnej teorii w sferze ludzkiego poznania ${ }^{7}$. Przeto i kwestie kontemplacji, możliwości poznania Boga czy życia w stanie zbawienia będą mieściły się w podwójnej opcji: obiektywności i osobistego zaangażowania.

${ }^{5}$ É. Gilson, Tomizm. Wprowadzenie do filozofii św. Tomasza z Akwinu, thum. J. Rybałt, Warszawa 1998, s. 428-429. Badacz w związku z wyłożoną kwestią dodał rzecz wysoce charakterystyczną: teologia św. Tomasza jest dziełem filozofa, a jego filozofia jest dziełem świętego, tamże, s. 17. Podobnie sądził M.D. Chenu, zauważając, że w ujęciu św. Tomasza kontemplacja pozostaje źródłem, zasadą i celem życia (le principe et la fin de sa vie), jak również i samej teologii, czemu średniowieczny myśliciel dawał wyraz w językowej manierze, jaką odnajdujemy w Wyznaniach św. Augustyna. Zob. tegoż, St. Thomas d'Aquin et la théologie, Paris 1959, s. 52 [tłum. polskie: A. Ziernicki, Kraków 1997, s. 56].

6 Tomasz z Akwinu, O prawdzie I, 5, w: tegoż, Kwestie dyskutowane o prawdzie, thum. A. Aduszkiewicz, L. Kuczyński, J. Ruszczyński, Kęty 1998, t. 1, s. 15.

${ }^{7}$ R. Heinzmann, Filozofia średniowieczna, tłum. P. Domański, Kęty 1999, s. 200-201. 
Naturalnie, muszę od razu dodać, że św. Tomasza zajmowały nade wszystko problemy, które obejmujemy formułą teologia mistyki (w odróżnieniu od teologii mistycznej), stąd nie tyle rozważał on treści własnego doświadczenia $^{8}$, które ewentualnie miałyby tajemniczy posmak, ile raczej zastanawiał się nad istniejącymi już teoriami w tym względzie, próbował dociekać ich struktury i powiązań z tekstami biblijnymi oraz dyskutował z poglądami funkcjonującymi w teologiczno-filozoficznych dyskusjach swego czasu. Co miał do badawczej dyspozycji? Przede wszystkim te fragmenty Biblii, gdzie opisuje się spotkania człowieka z Bogiem, tym bardziej że niektóre z wielkich postaci, tacy jak Abraham, Jakub, a zwłaszcza Mojżesz i św. Paweł bądź św. Jan Ewangelista, byli traktowani jako wzorcowi mistycy, a ich doświadczenia i biografie stały się modelem, za którego pośrednictwem inni poszukiwali kontaktu z Bogiem ${ }^{9}$ Dysponował również propozycjami chrześcijańskich mistrzów duchowych, dawnych i swoich czasów, głównie franciszkanów i dominikanów, ale i św. Augustyna, Pseudo-Dionizego Areopagity, ale również zwracał się do greckich ideałów kontemplacyjnych (Platona, Arystotelesa, Filona, Plotyna, Proklosa) i odkryć filozofów arabskich.

Jednak przede wszystkim żył w aurze wiary, przyjmując na jej mocy istnienie Boga, ustawicznie czerpiąc z treści płynących z objawienia. Jego dzieła wyrastają z gleby ewangelicznej, nie tylko wskutek określonej opcji religijnej, umieszczającej zamysł filozoficzny w granicach kreślonych przez wiarę, ale także i po prostu dlatego, że wynika to nieuchronnie z samej genezy pism św. Tomasza, stanowiących raczej propozycję mistrza teologii, który nie jest przede wszystkim profesorem w takiej czy innej szkole, choćby to był nawet Uniwersytet Paryski, ale budowniczym wiary, który daje organiczny wyraz Ewangelii Chrystusa i tworzy jej publiczną architekturę w społeczności ziemskiej, tej chrześcijańskiej i tej pogańskiej ${ }^{10}$. Stąd prawie każdy rozdział Summy

${ }^{8}$ Mam tu na myśli to, co się św. Tomaszowi przydarzyło 6 grudnia 1273 roku. Pomijając warstwę legendarną, wypada stwierdzić, że wówczas dominikański mnich postanowił zaprzestać pisania. $Z$ jakich racji? Może został olśniony potęgą mistycznego uniesienia albo doznał jakiejś formy załamania nerwowego - trudno orzec z całą stanowczością. W każdym razie nie dokończył Summy teologii, zdając się na milczenie, z którego przecież, jak sam nauczał, rodzi się wiara i „święta nauka" (sacra doctrina). Kiedy bowiem mówimy aż do granic możliwości i wypowiadalności, wtedy odkrywamy to milczenie. Wtedy też teolog odsłania jedynie imię tego milczenia, z którego wychodzi Słowo i do którego wraca. Jego imię to Bóg. Zob. D. Turner, Tomasz z Akwinu. Portret, thum. M. Romanek, Poznań 2017, s. 54-61. Nie będę też odnosił do rozważań prowadzonych przez św. Tomasza formuły „filozoficzna mistyka” w rozumieniu, jakie nadał jej Karl Albert w swojej pracy Wprowadzenie do filozoficznej mistyki (tłum. J. Marzęcki, Kęty 2002), gdyż poglądy św. Tomasza daleko odbiegają od tego rodzaju propozycji.

${ }^{9}$ Zob. B. McGinn, Fundamenty mistyki. Obecność Boga. Historia mistyki zachodniochrześcijańskiej (do Vwieku), dz. cyt., s. 4.

10 Por. M.D. Chenu, Święty Tomasz z Akwinu i teologia, thum. A. Ziernicki, W. Szymona, Kraków 1997, s. 89. 
przeciw poganom kończył św. Tomasz cytatami z Pisma Świętego, chcąc pokazać, że właśnie ono wypełnia ostatecznie wszelkie jego filozoficzne zamierzenia i interpretacyjne propozycje.

\section{Bóg powinien istnieć}

Ponieważ dla ludzkiego rozumu istnienie Boga - wbrew opinii ówczesnych augustynistów, na czele z Bonawenturą ${ }^{11}$ - wcale nie jest oczywiste, wszak nie można istnienia po prostu wywieść z istoty Boga ani uchwycić go żadną bezpośrednią intuicją, gdyż intuicja istnienia jest wrażeniem zmysłowym, a Boga nie można poznać zmysłowo, nie ma więc żadnego apriorycznego poznania Boga, dlatego św. Tomasz uruchomił językowo i logicznie precyzyjną metafizyczną procedurę, by - wychodząc od danych realnego świata oraz stosując zasadę przyczynowości - dowieść, że Bóg powinien istnieć, a wiara w Niego nie jest zwykłym fantazjowaniem, ale ma racjonalne podstawy. Poznanie istnienia Boga, jak i wszelkie inne poznanie, musi według niego wychodzić z poznania zmysłowego i posługiwać się odpowiednimi krokami: separacją, abstrakcją i analogią ${ }^{12}$. Człowiek przeto powinien mieć szansę, by poznać Boga i mówić o Nim w sposób sensowny, pozbawiony irracjonalnych wyobrażeń.

$\mathrm{Z}$ drugiej strony jednak warto mieć na uwadze fakt, że jednoznaczne określenia $\mathrm{w}$ stosunku do Boga nie są w ogóle możliwe, gdyż powodują poznawczą i ontyczną idolatrię. Zdani jesteśmy na mówienie analogiczne, apofatykę, milczenie i kontemplatywne doznania. Wszak najbardziej przejrzyste konstrukcje intelektualne św. Tomasza zawsze są umieszczone w swego rodzaju „ciemnym horyzoncie”, który trzeba nazwać horyzontem dionizjańskim $^{13}$. Ilekroć bowiem w średniowiecznej filozofii jest mowa o ciemnościach

11 Doktor Seraficki pisał: „Czyste istnienie samo w sobie jest do tego stopnia absolutnie pewne, iż nie może być pomyślane jako nieistniejące, ponieważ w pełni czyste istnienie zachodzi jedynie przy całkowitej ucieczce od nieistnienia i vice versa" - Bonawentura, Droga duszy do Boga i inne traktaty, tłum. C. Napiórkowski, Poznań 2001, s. 56.

12 Zob. S. Swieżawski, Dzieje europejskiej filozofii klasycznej, dz. cyt., s. 651.

13 Zagadnienie należy do dosyć skomplikowanych. Z jednej bowiem strony św. Tomasz niemal bez reszty eliminuje metodę Pseudo-Dionizego posługiwania się symboliką, traktując metaforę jak językowe kalectwo, po prostu ogołaca z elementów ściśle literackich wszelkiego rodzaju teksty, nie wyłączając tekstów Pisma Świętego oraz zapisów przeżyć mistycznych. Wszędzie bowiem poszukuje takiego poziomu języka, który trzeba nazwać konsubstancjalnym, czyli takim, który prowadzi do istoty myśli. Z drugiej jednak strony, naturalnie jasność słów nie zakrywa przed Doktorem Anielskim tajemniczości rzeczy. Zob. E.L. Mascall, Istnienie $i$ analogia, thum. J.W. Zielińska, Warszawa 1961, s. 73-98; M.D. Chenu, Wstęp do filozofii św. Tomasza z Akwinu, tłum. H. Rosnerowa, Kęty 2001, s. 112-119; M.A. Krąpiec, Teoria analogii bytu, Lublin 1993, s. 17-48; J. Sochoń, Bóg i język, Warszawa 2000, s. 151-178; É. Gilson, Tomizm, dz. cyt., s. 132-137; A. Biela, Analogia w nauce, Warszawa 1989. 
przesłaniających jasność rozumowego widzenia, można się domyślać bliskości Areopagity, którego zresztą św. Tomasz z upodobaniem cytował. Horyzont dionizjański nie oznacza naturalnie zgody na postawy irracjonalne czy fideistyczne; jest natomiast wyrazem ograniczoności wszystkich ludzkich możliwości. Owa „ograniczoność” jednak stała się i wciąż staje powodem aktywności filozoficznej uczonych, nie wyłączając z ich grona św. Tomasza z Akwinu.

W perspektywie wyznaczonej przez tego ostatniego ziemskie poznanie Boga wiąże się nierozerwalnie z promocją wiary i rozumu, dzięki którym zjawia się szansa kontemplowania prawdy, a także stosowania do Boga utworzonych przez ludzi formuł językowych, przy oczywistych ograniczeniach, jakie $\mathrm{z}$ tego faktu wynikają. Głównie sprowadzają się one do fundamentalnej konstatacji, że w żadnym razie określenia nadawane Bogu nie będą mogły wyjawiać Jego istoty. Święty Tomasz nie potrafił oddalić przypuszczenia o niewyrażalności Boga. Jesteśmy w stanie uzasadnić prawdę zdania „Bóg jest”, lecz - w tym jedynym przypadku - nie możemy zrozumieć znaczenia owego ,jest”. Jednak możliwość nazywania Boga, tak jak to w ludzkiej perspektywie możliwe, atut przybliżania się do Jego ontycznej tajemnicy wart bywa stałego trudu. Toteż św. Tomasz podjął wiele lingwistycznych procedur, by realizować powyższy cel. Na tym etapie rozważań wystarczy rozeznać, że metafizycznie najbardziej przydatne okazują się nazwy „niezupełnie wieloznaczne”, mieszczące się między jednoznacznością a wieloznacznością, zwane nazwami analogicznymi.

Nie może być jednak inaczej, gdyż nasze ludzkie poznanie jest ograniczone; ponadto musi być zachowana różnica (w bytowaniu i poznaniu) między naszym światem a Absolutem. Poznając, że istnieje Absolut, nie poznaje się w sensie pozytywnym ani Jego konkretnych relacji do świata, ani nie dociera się wprost do Jego istnienia. To, co jest nam w tej kwestii dostępne, ustalamy w filozofii na podstawie analizy skutków oraz przejawów działania Absolutu. Poznajemy Go więc o tyle, o ile jest On racją ontyczną wszystkiego, co istnieje. Naturalnie owo poznanie nie dotyczy treści (istoty, formy) relacji świata i Absolutu, lecz dokonuje się na płaszczyźnie istnienia. Jest tu więc jakieś podobieństwo, ponieważ każdy byt skończony jest podobny do Boga przez sam fakt istnienia, a jednak Bóg nie jest podobny do owego bytu skończonego. $\mathrm{Z}$ tego powodu - powtórzmy dobitnie - raczej afirmujemy Boga niż Go poznajemy w pełni Jego bytu. Co najwyżej (a to wszak niemało) rozeznajemy Go jako zewnętrzną przyczynę rzeczywistości złożonej i zmiennej.

Oto każdy byt jest podobny do Boga przez fakt istnienia, a zarazem istnieje dzięki podobieństwu do natury Bożej. Może Boga nazywać, choć nigdy nie dotrze do Jego istoty ${ }^{14}$. Jednakże w teologicznej i religijnej perspektywie

${ }_{14}$ Zob. szerzej: Z.J. Zdybicka, Partycypacja bytu. Próba wyjaśnienia relacji między światem a Bogiem, Lublin 2017. 
widać, że jesteśmy w stanie dostąpić najmocniejszego z możliwych w granicach ludzkiej natury darów: bliskości z Bogiem na wieki w tajemnicy zmartwychwstania. Metafizyka podprowadza pod próg tak wyartykułowanej nadziei. Zaprasza do językowego wysławiania Boga i milczenia, które również jest językiem, tyle tylko, że bezsemantycznym. Próbuje objaśniać też sam akt poczucia naocznej obecności bytu transcendentnego, który jest faktem odnotowanym po wielekroć i od dawien dawna na różne sposoby artykułowany w tradycjach religijnych. Jakie propozycje zgłaszał w powyższej sprawie św. Tomasz z Akwinu?

\section{Tomaszowe słowo serca}

Sposoby poznania i nazywania Boga, powiada św. Tomasz, łączą się bezpośrednio ze sobą, gdyż każdą rzecz nazywamy w takiej mierze, w jakiej ją poznajemy ${ }^{15}$. Nawiązując do tradycji, zastanawia się on nad samym językiem, interpretując głównie stanowisko Arystotelesa, który odrzucał wszystkie teorie pochodzenia języka, które mają charakter religijny. Niekiedy uważano bowiem, że skoro Bóg stworzył człowieka jako istotę społeczną, musiał mu dać także język ${ }^{16}$. Podobne intuicje ujawniają karty Starego Testamentu. Inni badacze postulowali „naturalny” związek brzmienia wyrazów z ich znaczeniem. Chodzi tu o koncepcję dźwiękonaśladowczą (Platon, Lukrecjusz, Herder). W nieco innej wersji to przekonanie funkcjonowało jako teza, że ludzie nauczyli się języka, naśladując dźwięki wydawane przez zwierzęta, albo że język powstał z kasłania, kichania, wycia i jęczenia (Rousseau, Darwin) bądź z wokalizowania. Z biegiem czasu ukształtowało się przeświadczenie, że język jest tworem społecznym, powstał na drodze naturalnego rozwoju z potrzeby porozumiewania się w pewnej społeczności.

Ciekawe jest właśnie to upodobanie do porozumiewania się, chęć interakcji z innymi ludźmi w ramach aktywności zwanej kulturą. Bez języka większość pojęć byłaby niewyobrażalna i niewyrażalna. Nie mielibyśmy na przykład matematyki czy poezji. Najlepiej jednakowoż zaakceptować pogląd Arystotelesa o tym, że znaczenie jest kwestią umowy, nie może natomiast

${ }^{15}$ Praeterea, secundum hoc nominatur aliquid a nobis, secundum quod inteligitur $-\mathrm{S}$. Thomae Aquinatis, Summa Theologiae I, q. 13, art. 2, ad. 3.

${ }^{16}$ Pomijam tutaj zagadnienie wiążące się z faktem nazywania Boga za pomocą wyrażenia Logos-Słowo i różnorakimi konsekwencjami, jakie wspomniany akt niesie. To zakorzenione w tradycji imię Boga odnosi się nie tylko do drugiej Osoby Trójcy Świętej, lecz także do Osoby Trzeciej, którą również określamy mianem odsyłającym do koncepcji języka, gdyż Bóg to także Duch lub Tchnienie, a więc jest podstawą mowy. Niebywale intrygująco pisze o tych kwestiach Michael Edwards w pracy Ku poetyce chrześcijańskiej, tłum. M. Szuba, Gdańsk-Pelplin 2017, s. 243-263. 
tkwić w formach języka istniejących w swego rodzaju platońskiej (niebiańskiej) pleromie. Język buduje i tworzy społeczeństwo w ramach wspólnego wysiłku podejmowanego przez ludzi w celu zaspokojenia ich instynktu społecznego ${ }^{17}$. W związku z powyższym autor Metafizyki odróżniał nazwy proste i złożone, konkludując, że one mają znaczenie nadawane ze społecznej konwencji. Stąd mowa jest znakiem myśli, ponieważ mowa zewnętrzna (system znaków językowych) przyporządkowana jest w sposób konwencjonalny mowie wewnętrznej (myślom). Z kolei myśli są znakami przedmiotów, a pismo jest znakiem mowy.

W każdym razie Arystoteles przekonywał, że język służy ludziom przede wszystkim do utrwalania wiedzy, gromadzonej w umyśle pod postacią pojęć, których znakami są nazwy. Mamy tutaj zatem do czynienia z sytuacją, w której istotne są relacje między nazwami a znaczeniami. Gdy przebiegają one bez żadnych zakłóceń, a my, wychodząc od danych zmysłowych stosujemy naturalnie metodę abstrakcji, wówczas uzyskujemy możność zdobycia rzeczywistej wiedzy o świecie. Język bowiem nie jest w tym procesie przeszkodą czy nieprzekraczalną barierą, lecz wspomagającym środkiem poznawczym. Łączy bezpośrednio z fizyczną realnością. W ujęciu św. Tomasza mamy do czynienia z dwoma rodzajami słów, które pełnią funkcje oznaczania, lecz w sposób odmienny. Słowo zewnętrzne (cielesne, wyartykułowane, przemijające) nie łączy się ze swym pojęciem koniecznościowo, zaś słowo wewnętrzne - w sposób konieczny. Wszak pojęcie przedstawia sobą samą rzecz, dlatego nie może być mowy o konwencji czy dowolności. Dopiero jednak tzw. słowo serca (verbum cordis $)^{18}$, wypowiedziane bez głosu orzeka w ścisłym sensie o Bogu, ponieważ to słowo jest całkowicie oddalone od materialności i cielesności oraz jakiegokolwiek braku. W przeciwieństwie słowo wewnętrzne i słowo wypowiedziane (wyrażone na zewnątrz) może być o Bogu wyrażane wyłącznie metaforycznie ${ }^{19}$.

Jakie zatem są szanse poznania przez ludzi samego Boga? Czy Bóg przedstawia się nam jako całkowicie niepoznawalny, czy tylko nie potrafimy dotrzeć do Jego istoty. Raczej drugi z przywołanych poglądów zdaje się przyjmować św. Tomasz. Nie potrafimy dojrzeć Boga dzięki zmysłowym narzędziom

17 Platon odrzucał zarówno teorię naturalnej, jak i konwencjonalnej zgodności słowa i rzeczy. Uważał, że szansa dotarcia do świata idei otwiera się tylko w porządku znajdującym się ,,poza nazwami", a więc możemy się doń zbliżyć tylko wówczas, kiedy w ogóle nie będziemy posługiwali się słowami. Zob. tegoż, Kratylos 438d, tłum. Z. Brzostowska, Lublin 1990, s. 13-131; zob. też: D.L. Everett, Język. Narzędzie kultury, tłum. Z. Wąchocka, P. Paszkowski, Kraków 2018.

18 Augustyn powiadał, że niektóre ludzkie myśli stanowią mowę serca, gdyż również serce ma swoje usta. Jednakże to słowo serca nie należy do żadnego języka, jest natomiast zwierciadłem i obrazem Słowa Bożego. Zob. tegoż, O Trójcy Świętej XV, X 18-20, tłum. M. Stokowska, Kraków 1996, s. 481-483.

19 Tomasz z Akwinu, O słowie, w: tegoż, Kwestie dyskutowane o prawdzie, q 4, a. 1, dz. cyt., S. 181 
poznawczym. Potrafimy Go natomiast uchwycić pośrednio, odwołując się do „językowych mocy”. Czym innym zaś będzie ten rodzaj „oglądu Boga”, o którym wspominają księgi Biblii. Stąd też św. Tomasz proponuje odpowiednią terminologię: cognitio będzie odnosić się do poznania dostępnego w porządku ziemskiego doświadczenia, natomiast visio określa ludzką sytuację poznawczą zaistniałą już po stronie zmartwychwstania. W związku z tym średniowieczny filozof uznał, że na ziemi dosłownie wszystkim ludziom przysługuje zdolność do zdobywania pewnej wiedzy o Bogu. To oczywiście nie jest pełna erudycja o Stwórcy, a jedynie taka, która bywa wynikiem refleksji nad skutkami Bożej, opatrznościowej działalności. Chcąc bowiem przeniknąć w głąb Bożej istoty, musielibyśmy dysponować for mą z m y sło w e g o wejrzenia w Bożą naturę.

\section{Poznanie wzbogacone laską}

Natomiast sprawy zupełnie wyjątkowe dzieją się, gdy rozważamy ludzkie poznanie wzbogacone łaską, która zresztą jest przez Boga rozdzielana w sposób znany tylko Jemu samemu. Wtedy zwiększają się moce rozumowe, zaś wyobrażenia formowane w wyobraźni silniej wyrażają „,coś boskiego”, na przykład prawdy typu revelata (tajemnica Trójcy Świętej, wcielenie itd.). Owo pełniejsze poznanie Boga wciąż jednak pozostaje poznaniem łączącym człowieka z Bogiem jakby z nieznanym, gdyż łaska działa wyłącznie w zakresie wyznaczonym przez przyrodzone własności ludzkiej natury. Stąd doświadczane stany mistyczne nie sprawiają, że poznajemy Bożą istotę. W perspektywie arystotelesowsko-tomistycznego realizmu nie może nigdy zachodzić przyrodzone, bezpośrednie i doświadczalne poznanie Boga, więc i nie może być czegoś takiego jak przyrodzona mistyka. Ona zawsze występuje na gruncie życia nadprzyrodzonego jako skutek łaski działającej zresztą również i poza Kościołem widzialnym. Metafizyka nigdy nie będzie w stanie zastąpić teologii i przeobrazić się w mistykę ${ }^{20}$. Stąd też nawet w stanie zbawienia - zdaniem św. Tomasza - nie ulegnie zmianie natura ludzkiego poznania. Poznanie przynależne człowiekowi jako takiemu nigdy nie zmieni swej natury. Będzie zawsze czymś, by tak rzec, wciąż oczekującym na dopełnienie.

Niemniej jednak św. Tomasz wie, że Bóg może działać według swej woli w sposób niczym niedeterminowany. Zdarza się więc, że cudownie obdarza On kogoś darem bezpośredniego oglądania samego siebie już w ziemskim, przygodnym bytowaniu. W normalnym stanie rzeczy jednak formą poznania Boga,

20 Święty Tomasz powiada, że gdyby człowiek potrafił w życiu doczesnym poznawać Boga w nim samym, byłoby to niezgodne z naturą, tak jak gdyby noworodek miał brodę. Zob. tegoż, Kwestie dyskutowane o prawdzie, q. 13, a. 1. 
prowadzącą do nadprzyrodzonego z Nim spotkania jest visio. Księgi Biblii metaforycznie raz sugerują, że żadne istotowe poznanie Boga - nawet w stanie zbawienia - nie jest w ogóle możliwe, innym razem zaś powiadają, że szczęście zbawienia utożsamia się zasadniczo z o g lą d a n i em B o g a. Z tego obrazowania wzięły się dwie tradycje interpretacyjne: grecka i łacińska. Pierwsza z nich ogranicza się do stwierdzenia, że możliwy jest tylko ogląd boskich teofanii, co wyklucza poznawcze dotarcie do istoty Boga (Grzegorz z Nyssy, Pseudo-Dionizy Areopagita, Jan Chryzostom). Transcendencja Boga jest mocna i pozbawiona jakichkolwiek łączności z człowiekiem. Tradycja łacińska, głównie wiążąca się z dokonaniami św. Augustyna, podkreśla, że oglądanie Boga pozostaje głównym celem ludzkiej aktywności i treścią zbawienia ${ }^{21}$.

Tomasz, jak postuluje wielu badaczy, wybiera drogę pośrednią. Jakże wyobrazić sobie - pyta - życie pozbawione bliskości z Bogiem? Bez Niego nie miałoby ono żadnego sensu. Nie po to otrzymaliśmy rozum, wolę i serce, by pozostawać na poziomie kukiełek w rękach ślepego losu. To, że dysponujemy władzą intelektualną, która umożliwia przez abstrakcję przyjmowanie Bożej łaski, predestynuje nas do umacniania nadziei na otrzymanie zbawczego oświecenia. Jego natężenie będzie zależało od natężenia naszej miłości, tu na ziemi. Tomasz, w rzeczy samej imponująco, napisał:

Zdolność oglądania Boga nie przysługuje intelektowi stworzonemu zgodnie z jego naturą, lecz przez światło chwały, które nada intelektowi poniekąd kształt Boga. Toteż intelekt głębiej uczestniczący w świetle chwały zobaczy Boga w sposób bardziej doskonały. W większym stopniu zaś będzie uczestniczył w świetle chwały ten, kto będzie miał więcej miłości, ponieważ gdzie rozkwita większa miłość, tam pojawia się zwiększone pragnienie, a pragnienie niejako czyni pragnącego zdolnym i gotowym na przyjęcie przedmiotu pragnienia. Kto więc będzie bardziej miłował, otrzyma doskonalsze widzenie Boga i okaże się szczęśliwszy²2.

Łączy on zatem precyzję racjonalnego wywodu z zaangażowaniem religijnym, a równocześnie przedstawia wizję zbawienia: oto bowiem zbawieni nie mają identycznej wiedzy o Bogu i równego szczęścia. Kto szlachetniej kochał, ten znajdzie się w bardziej intensywnej jedności z umiłowanym Stwórcą. Jednakże ów stan „unii z Bogiem” nie zniweczy ludzkiej natury. Pozostanie ona taka sama, choć udoskonalona.

${ }^{21}$ Zob. szerzej: M. Olszewski, Komentarz do Kwestii 12. W jaki sposób poznajemy Boga, w: Tomasz z Akwinu, Traktat o Bogu. Summa teologii, kwestie 1-26, thum. i kom. G. Kurylewicz, Z. Nerczuk, M. Olszewski, Kraków 1999, s. 589-608; M. Stróżyński, Kontemplacja Boga u św. Augustyna w perspektywie ewolucji jego filozofii, „Filozofia Chrześcijańska” 2017 nr 14, s. 87-105; S. Gaworek, «Dotknięcie» Boga w doświadczeniu mistycznym wedtug św. Augustyna, „Warszawskie Studia Teologiczne" $2011 \mathrm{nr}$ 2, s. 209-220.

${ }^{22}$ Thome Aquinatis, Summa theologiae I, q. 12, art. 6. 
Powyższe rozstrzygnięcia mają istotne znaczenie w kwestii przeżyć mistycznych, o których traktują różnego rodzaju teksty, zarówno biblijne, jak i przechowywane w duchowej historii chrześcijaństwa. Do nich najczęściej odwołuje się św. Tomasz i - mimo napotykanych trudności - udało mu się syntetycznie ująć fenomen doświadczenia mistycznego, który w późniejszych wiekach zyskał miano ujęcia modelowego, wzorcowego. Oto najbardziej ogólny, niemal definicyjny, jego opis. Najwyższy, wewnętrzny, pobudzony przez miłość, stan człowieka, a właściwie jego umysłu, w którym odczuwa on bezpośrednio (intuicyjnie), a więc bez najmniejszej nawet domieszki form wyobrażeniowych oraz intelektualnych, obecność bytu transcendentnego nazywamy stanem mistycznego uniesienia i zachwytu, w najgłębszym swym wymiarze będący wzniosłą kontemplacją Bożej Prawdy, jasnym widzeniem Boga, pozbawionym jednakowoż możliwości intersubiektywnego wejścia w powszechną świadomość innych osób.

Dodajmy przy tym, że ów stan charakteryzuje przedziwny paradoks. Kto bowiem zostaje objęty jego tajemnicą, niczego z niej nie jest w stanie (w intersubiektywnych znakach) przekazać; ten zaś, kto takiej wizji nie przeżył, nie może wiedzieć, na czym ona zasadniczo polega. Niezbyt zatem wiele daje się uchwycić z duchowej relacji, jaka od wieków trwa między człowiekiem a Bogiem. Najczęściej bywamy zdolni jedynie do apofatycznych gestów, często przybierających charakter wypowiedzi artystycznych, głęboko zmetaforyzowanych, oraz świadomości własnej przygodności. Nie jesteśmy więc w stanie wykroczyć poza determinacje niesione przez ludzki sposób bytowania i poznawania.

Tym jednakowoż, co w tym procesie pozostaje niezmienne, jest akceptacja istnienia Stwórcy oraz wiara w odkupieńczą moc Jezusowej Krwi, scalające w jeden religijny akt wysiłki wierzących, zwłaszcza tych, którzy odkryli w sobie szczególną łaskę, płynącą ze strony samego Zbawiciela, dzięki której ich świadomość zyskuje wymiar mistyczny, co najczęściej oznacza, że zjawia się ona jako wynik słuchania, interpretowania i głoszenia treści zawartych w Biblii. Hermeneutyka słowa prowadzi w takim przypadku do głębokiej ekstazy. Materią dyskusyjną pozostaje, na ile tego rodzaju wizja jest w ścisłym sensie poznaniem, a na ile tylko poczuciem jedności, duchowej unii, specyficznym zjednoczeniem, gdzie człowiek pozostaje człowiekiem, a Bóg Bogiem. I czy sięga ostatecznie istoty Boga? 


\section{Mistyczne porwanie duszy}

By odpowiedzieć na powyższe kwestie, św. Tomasz nawiązał do wydarzenia biblijnego, mianowicie do tekstu św. Pawła, który - jak to ujął Benedykt $\mathrm{XVI}^{23}$ - w Drugim Liście do Koryntian $(12,1)$, zwracając się do tych, którzy podawali w wątpliwość podstawy jego apostolatu, nie skupia się na wyliczaniu wspólnot, które założył, kilometrów, które przemierzył; nie ogranicza się do przypomnienia trudności i sprzeciwów, jakim stawiał czoło, by głosić Ewangelię, ale wskazuje na swoją więź z Panem, więź tak zażyłą, że przeżył również chwile ekstazy, głębokiej kontemplacji; nie chwali się zatem tym, czego dokonał, swoją siłą, swoją działalnością i osiągnięciami, ale tym, co sprawił w nim Bóg i czego dokonał w innych za jego pośrednictwem. $Z$ wielkim zawstydzeniem opowiada więc o swoim szczególnym przeżyciu, jakim była chwila porwania, pochwycenia do Bożego nieba.

Oto, przypomina, 14 lat przed wysłaniem Listu ,został porwany aż do trzeciego nieba". Językiem i środkami wyrazu człowieka opowiadającego o czymś, czego wysłowić się nie da, św. Paweł mówi o tym fakcie, posługując się trzecią osobą; oznajmia, że ów człowiek został porwany do „ogrodu” Boga, do raju. Kontemplacja jest tak głęboka i silna, że apostoł nie pamięta nawet treści otrzymanego przekazu, zna jednak dobrze datę i okoliczności, w których Pan tak całkowicie go pochwycił, przyciągnął do siebie, jak na drodze do Damaszku w momencie jego nawrócenia (por. Flp 3,12).

Czym zatem byłoby wspomniane przez św. Pawła „porwanie”? Chodzi o taką niespodziewaną i nagłą sytuację, w której Bóg unosi kogoś w duchowe rejony nadprzyrodzoności, już poza oddziaływaniem jakichkolwiek zmysłów ${ }^{24}$. Jest to możliwe, ponieważ człowiek został stworzony na Boży obraz i podobieństwo, a nadto tego rodzaju wyniesienie jest zgodne z ludzką naturą i wiąże się z ludzkim sposobem istnienia oraz godnością człowieka. Dokonuje się ono zasadniczo w sferze poznawczej, choć może skutkować w dziedzinie pożądawczej, mianowicie wówczas, gdy osoba porwana do „raju” doznaje $\mathrm{z}$ tej racji wielkiej uczuciowej błogości. Trudno naturalnie w tym opisie uchwycić ściśle różnicę między kontemplacjąą, zachwyceniem,

${ }_{23}$ Benedykt XVI, Bóg działa w stabości. Audiencja generalna 13 czerwca 2013, „L'Osservatore Romano" 2012 nr 9-10, https://opoka.org.pl/biblioteka/W/WP/benedykt_xvi/audiencje/ ag_13062012.html [dostęp: 15.06.2018].

${ }^{24}$ Et sic loquimur nunc de raptu: prout scilicet aliquis spiritu divino elevatur ad aliqua supernaturalia, cum abstractione a sensibus - Thome Aquinatis, Summa theologiae II-II, q. 175, art. 1, ad. 3.

25 Święty Tomasz poświęca kontemplacji całe kwestie $(179,180-82)$ w Summie teologii, uznając kontemplację Bożej prawdy za główny i najważniejszy cel ludzkiego życia. Dokonuje się to oczywiście w sposób niedoskonały, „w zwierciadle i niejasno”, w pewnym poznawczym trudzie. Wylicza za Ryszardem ze św. Wiktora sześć stopni, po których wspina się człowiek, pobudzony przez miłość, by umysłowo dotrzeć do Boga, w prostym ujęciu Prawdy. Podkreśla przy tym zasad- 
ekstazą ${ }^{26}$ a stanem mistycznym, ponieważ są to terminy wieloznaczne i często ich zakres znaczeniowy w pewnych obszarach treściowych nakłada się na siebie, zasadniczo jednak pozostaje rozbieżny, choć metafora porwania umysłu (raptus) sugerowałaby w każdym z tych przypadków konieczność oderwania od używania narzędzi zmysłowych tudzież nadzwyczajną ingerencję samego Boga.

Definitywnie św. Tomasz sugeruje, że ekstaza sprowadza się do „wyjścia z siebie", a więc poza to wszystko, co determinuje przygodność człowieczego bytu i dokonuje się w porządku pożądawczym. Dlatego miłość może powodować ekstazę, jako że skłania ona pożądanie człowieka do dążenia ku rzeczom miłowanym ${ }^{27}$. Ekstaza przeto może być wywoływana przez najróżniejsze ziemskie czynniki, jak również przez miłość samego Boga i miłość człowieka do Boga. Wówczas umysł zostaje oderwany od aktywności zmysłowej i wchodzi na poziom nadnaturalny, przy zachowaniu działania intelektu oraz wyobraźni. Natomiast raptus tym się charakteryzuje, że owładnięta nim osoba widzi Boga poprzez boską istotę (videre Deum per essentiam) ${ }^{28}$.

Czy to jednak możliwe w ziemskiej rzeczywistości? Tomasz przekonuje, że owszem, gdyż św. Paweł, jak też Mojżesz, byli tymi właśnie ludźmi, którzy w ograniczoności ziemskiego życia, w chwili zachwycającego porwania (raptus) dostąpili łaski widzenia Boga w Jego istocie. Mogło się to jednak dokonać tylko przy spełnieniu określonych warunków i było to wydarzenie

niczą wyższość życia kontemplatywnego od życia zaangażowanego w sprawy tego świata, choć dodaje, że jeżeli ktoś z życia kontemplatywnego został wezwany do życia czynnego, powinno się to stawać nie ze szkodą dla życia kontemplatywnego, ale z jego wzbogaceniem (tamże, II-II, q. 182, a. 1). W rzeczywistości więc św. Tomasz, oddzielając ze względów logicznych życie aktywne i kontemplacyjne (tak, jak przyjął za Arystotelesem podział intelektu na czynny i bierny), nie proponuje, by czynić tak w praktyce egzystencjalnej, gdyż życie aktywne i kontemplacyjne polega na różnej proporcji elementów składowych, nie zaś na wyłączności któregoś; zob. też: M. Górnicki, Antropologia czternastowiecznych mistyków angielskich, Lublin 2018, s. 144-145; R. Van Nieuwenhove, «Recipientes per contemplationem, tradentes per actionem»: The relations befween the active and contemplative lives according to Thomas Aquinas, „The Thomist” $2017 \mathrm{nr} 81$, s. 1-30; R. Van Nieuwenhove, «Recipientes per contemplationem, tradentes per actionem»: The relations between the active and contemplative lives according to Thomas Aquinas, „The Thomist” $2017 \mathrm{nr} 81$, s. 1-30.

26 Izabela Andrzejuk słusznie wskazuje na ważną sprawę odróżnienia ekstazy od lumen gloriae, jak również pyta, czy przypadkiem Tomaszowa interpretacja raptum nie jest właściwie tym samym, co Bonawenturiańskie poznanie per raptum, i sugeruje, że Tomasz pozostaje o włos od rozwiązań św. Bonawentury, określającego poznanie per raptum jako akt światła chwały, a samo lumen gloriae jako sprawność. Dla św. Bonawentury poznanie per raptum związane jest z najwyższym etapem rozwoju życia duchowego człowieka i dzieje się właśnie w jego szczytowym momencie. Tomasz jednak nie posługuje się tym odróżnieniem, ale nazywa światło chwały sprawnością, jednakże nie decyduje się na nazwanie raptus aktem chwały i nie wiąże go też z określonym etapem życia religijnego. Zob. tejże, Kontemplacja i poznanie "per raptum». Tomaszowe źródła rozumienia istoty doświadczenia mistycznego, ,Rocznik Tomistyczny” 2017 nr 6, s. 6-67.

27 Thome Aquinatis, Summa theologiae II-II, q. 175, art. 2, ad. 1.

28 Et idei convenientius dicitur quod Deum per essenctiam vidit-tamże, II; q. 175, art. 3. 
jedyne w swoim rodzaju, odosobnione, przynoszące przejściowe szczęście, choć o najwyższym natężeniu. Musiało po prostu nastąpić, dzięki uprzedzającej Bożej ingerencji, spotęgowanie czy oświecenie ludzkiego intelektu, a więc musiało rozbłysnąć, jak to określa św. Tomasz, światło chwały ${ }^{29}$, które nadaje intelektowi w pewien sposób ,profil Boga”, co oznacza, że istota Boga staje się poznawczo obecna w podmiocie poznającym. Ona sama więc, bo przecież nie może to czynić żadne wyobrażenie albo pojęcie, boska istota aktualizuje ludzki intelekt, będąc zarazem tym, co (quod) się widzi, jak i tym, poprzez co (quo) się widzi ${ }^{30}$.

Dlatego właśnie musi nastąpić porwanie (raptus), by ludzka myśl, całkowicie oderwana od aktywności zmysłowej, mogła zostać wypełniona boską istotą. W ten sposób istota Boga zyskuje formę intelektualną ludzkiego intelektu. Tomasz motywuje to przekonanie racjami natury teologiczno-filozoficznej, powołuje się na autorytet św. Augustyna i teksty biblijne, zachowując przy tym swego rodzaju ostrożność interpretacyjną, gdyż uznaje doświadczenia Mojżesza i św. Pawła jedynie za wydarzenie przejściowe, niemogące być podstawą do szerszych uogólnień. Metafora „trzeciego nieba”, oznaczająca niebo duchowe, miejsce kontemplacji osób szczęśliwych z Bogiem, ale również pewne widzenie umysłowe, wskazuje, że Bóg (tylko na krótką chwilę) pozwolił przeżyć św. Pawłowi ten stan życia, w którym będzie on widział Boga przez całą wieczność.

To porwanie i zachwycenie było podobne do widzenia świętych w niebie pod względem tego, co się widziało, natomiast różniło się od widzenia w niebie pod względem sposobu widzenia, gdyż nie było to widzenie równie doskonałe, jak to charakteryzujące świętych $w$ niebie ${ }^{31}$. Kiedy więc św. Paweł przestał widzieć Boga w Jego istocie, to jednak zachował w pamięci to, co w tym widzeniu poznał, a to dzięki pewnym formom myślowym pozostałym $\mathrm{z}$ tego na stałe w jego myśli, co pozostaje zgodne z mechanizmem działania ludzkiej pamięci, podsycanej do działania pod wpływem przywoływanych wyobrażeń zdarzeń, które już przeminęły.

${ }^{29}$ Światło chwały (lumen gloriae) człowiek może otrzymać od Boga w dwojaki sposób. Po pierwsze, będąc już po stronie zmartwychwstania, pod postacią stałej formy czy siły wewnętrznej (formae immanentis), dzięki czemu zyskuje nieusuwalne szczęście wieczne, a po drugie, jako przejściowe przeżycie, przypominające przepowiadanie prorockie. Zdaniem św. Tomasza, porwanie (raptus) przynależy do tego drugiego rodzaju doznania. Zob. Thome Aquinatis, Summa theologiae II-II, q. 175, art. 3, ad. 2, również: A. Wohlman, Thomas d'Aquin et Maïmonide un dialogue exemplaire, Paris 1988, s. 294-317.

${ }^{30}$ Zob. P. Moskal, Tomasza z Akwinu epistemologia przekonań teistycznych, „Łódzkie Studia Teologiczne” 2014 nr 4, s. 5-16; A.R. Bańka, Josepha Maréchala interpretacja «jasnego widzenia Boga» w doktrynie mistycznej Tomasza z Akwinu, „Folia Philosophica” 2011 nr 29, s. 234-237.

${ }^{31}$ Thome Aquinatis, Summa theologiae II-II, q. 175, art. 6, ad. 3. 
Tomasz zatem, uznając przypadek św. Pawła za niebywale wyjątkowy, starał się wypunktowywać pewne bliskie wymiary jednoczące raptus ze światłem chwały, gdyż w obu przypadkach musi następować porzucenie porządku dosiężnego za pomocą poznania zmysłowego. Człowiek co prawda nadal pozostaje w porządku psychofizycznego scalenia, niemniej jednak nie korzysta z mocy zmysłów cielesnych bądź wyobraźni. Autor Wykładu Listu do Kolosan przyjął więc, że raptus jest najwyższym stanem kontemplacji, a jego specyfika polega na tym, że Bóg tak ,podnosi ludzki intelekt”, działający zgodnie $\mathrm{z}$ własną naturą, aby ten mógł poznać Boga. W tak pojętym bezpośrednim oglądaniu Boga intelekt ludzki jest całkowicie pogrążony w Bogu i niczego innego nie poznaje (nie rozmyśla, nie rozumuje) spośród tych rzeczy, które są wyobrażeniami.

Naturalnie, raptus swoją doskonałością nie dorównuje św ia ł łu chwały jako naocznemu widzeniu Boga po śmierci, choć w jakiś sposób można je do światła chwały porównać. Gdyby jednak utożsamić raptus ze światłem chwały, wówczas należałoby przyznać, że człowiek go doświadczający nie będzie już więcej grzeszył, zwrócony w stały sposób ku Bogu jako swojemu celowi - takie zresztą skutki przynosi bezpośrednie widzenie istoty Boga. Jednakże sytuacja taka nie zachodzi po doświadczeniu porwania umysłu ${ }^{32}$.

Zauważamy przeto, że choć sam Tomasz nie podejmuje wprost tematu doświadczenia mistycznego (zresztą, on w ogóle nie używa tego pojęcia), to jednak za taki można uznać omawiany przez niego wyjątkowy typ kontemplacji w postaci porwania umysłu. Odnotujmy ważniejsze jego cechy:

- raptus jest doznaniem nagłym, trwającym krótko, przemijającym;

- przekracza naturalne siły człowieka, gdyż to Bóg inicjuje porwanie;

- zawsze pozostaje czymś biernym, ponieważ doznaje jedynie intelekt człowieka i właśnie intelekt widzi w tym stanie istotę Boga;

- ma charakter wyraźnie zamknięty, z tej racji, że doznający raptus nie potrafi precyzyjnie wyrazić, co się właściwie wydarzyło;

- raptus dzieje się bez żadnej zasługi czy aktywności człowieka, który nie jest w stanie sam w sobie go wywołać.

Czyżby więc wydobyte z pism św. Tomasza cechy raptus były zarazem cechami doświadczenia mistycznego?

32 I. Andrzejuk, Kontemplacja i poznanie «per raptum». Tomaszowe źródła rozumienia istoty doświadczenia mistycznego, dz. cyt., s. 64. 


\section{Lumen gloriae}

Wypada teraz zaryzykować przekonanie, że wielkie teksty scholastyki są w zasadzie tekstami o wymiarze teologicznym. U św. Tomasza zjawia się w pewnym momencie intelektualna granica, na której zatrzymują się wszystkie działania metafizyczne, poza którą nie sposób już wyjść, mając do dyspozycji jedynie ludzkie możliwości poznawcze. Należy wówczas wejść na tereny teologii, a dokładniej mówiąc, w sferę teologalną, gdzie oddajemy Bogu cześć i żyjemy w kręgu wiary, nadziei i miłości. Wtedy też rozkwita w nas życie nadprzyrodzone i w ten sposób niejako upodabniamy się do Boga, choć dopiero w stopniu zalążkowym. Pełna realizacja tej możliwości nastąpi w wizji uszczęśliwiającej, kiedy to poznanie i miłość będą ze sobą najściślej powiązane.

Chodzi tu o łaskę płynącą od Boga, dzięki której człowiek osiągnął szczęście, czyli ogląda Boga. Łaską, która jest udzielana intelektowi, jest, powtarzał za św. Augustynem Tomasz, światło boskie (lumen gloriae) ${ }^{33}$, wzmagające jego zdolności poznawcze, póki nie uzyska on stanu widzenia istoty Boga - iluminacji. Oczywiście, jak już wspominałem, otrzymanie łaski widzenia Boga oraz jej stopień zależą od natężenia miłości (caritas) i pragnienia, z jakim chcemy ją otrzymać. Konsekwencję tego stanowi fakt, że zbawieni nie mają równej wiedzy o Bogu i równego, bo uzależnionego od niej, szczęścia.

Podkreślmy więc: św. Tomasz stanowczo odrzucał możliwość oglądania Boga w życiu doczesnym. Doświadczenia Mojżesza i Pawła uznawał za wyjątkowe zdarzenia, jeżeli nie uważa się ich za wizje zmysłowe, metaforycznie opisywane jako widzenie samego Boga. Doświadczenie mistyczne przebiegające w życiu doczesnym, które próbował opisywać, nie było dla niego rzeczywistością najważniejszą. Najbardziej pociągało go bezpośrednie widzenie Boga obiecane przez Pismo Święte, ponieważ, jak pisał, „będziemy widzieć Boga twarzą w twarz, dlatego że będziemy Go widzieli bezpośrednio, jak człowieka, którego widzimy twarzą w twarz. Zatem, dodawał, przy stole Boga jedzą i piją ci, którzy cieszą się tą samą szczęśliwością, która jest szczęściem Boga, i widzą Go tym samym sposobem, którym On widzi siebie"34.

Oznacza to, że w sferze nadprzyrodzonej trwa wieczny, nieprzerwany akt poznania Boga i zjednoczenia się z Nim. Przedmiot poznania jest w visio w większym stopniu aktywny niż podmiot. Widzenie Boga dokonuje się bez żadnego pośrednictwa. Jest ono dostępne - tak jak inne formy łaski - wybranym - każdemu według jego zasług i woli Boga. Charakterystyczne pozostaje

${ }^{33}$ Dicendum ergo quod ad videndum Dei essentiam requiritur aliqua similitudo ex parte visivare potentiae, seilicet lumen gloriae, confortans intellectum ad videndum Deum - Thomae Aquinatis, Summa Theologiae I, q. 12, art. 2.

34 Tomasz z Akwinu, Summa contra gentiles. Prawda wiary chrześcijańskiej III, 52, t. II, tłum. Z. Włodek, W. Zega, Poznań 2007, s. 149. 
wszak to, że w stanie zbawienia nie ulega zmianie natura ludzkiego poznania; to ten sam człowiek dąży tu na ziemi do poznania Boga i otrzymuje to poznanie $\mathrm{w}$ niebie, a zarazem zdaje sprawę $\mathrm{z}$ ludzkiej namacalnej doświadczalnie niesamowystarczalności w osiągnięciu szczęścia. Ten właśnie problem stanowi istotę Tomaszowych rozważań nad visio beatificans ${ }^{35}$.

$\mathrm{Z}$ przedstawionych tutaj interpretacji wydobywam kilka godnych dalszych przemyśleń stwierdzeń:

- Teologia mistyki św. Tomasza wywodzi się z zasadniczych tez realizmu metafizycznego, zwłaszcza z jego teorii poznania i antropologii, powiązanych mocnymi więzami z porządkiem religijnej wiary oraz dokonaniami teologii.

- Przeżyć zwanych mistycznymi doświadcza się w krajobrazach ziemskiej przygodności, w sferze poznania cognitio, które przynosi pewną o Bogu wiedzę, ale pośrednią i ułomną.

- Wyróżnioną formą przeżycia mistycznego jest stan zachwycenia (raptus), czyli cielesnego pochwycenia, porwania umysłu, złączony z działaniem władzy poznawczej, odróżniony wyraźnie od ekstazy, dokonującej się w sferze pożądawczej człowieka.

- Raptus, zdaniem św. Tomasza, może być rozpoznany jako bezpośrednie ujęcie przez ludzki intelekt istoty Boga, a więc tego, kim Bóg jest w swojej, niepojętej dla nas, osobowej prostocie.

- Raptus, jeżeli doznaje się go w przyrodzonej rzeczywistości, jest doznaniem przejściowym. Metaforycznie oznacza trzecie duchowe niebo, które Pawłowi pokazał Bóg, a które będzie mu dostępne w wieczności.

- Różnego rodzaju nadnaturalne zjawiska sprzeczne z działaniem sił naturalnych należy przypisywać diabłu, a nie Duchowi Świętemu.

- Autentycznym kryterium nadnaturalności jest miłość, a nie obecność fenomenologicznych osobliwości ${ }^{36}$.

- Mimo mocy nadprzyrodzonej łaski, mimo wsparcia lumen gloriae w zbawczych relacjach człowieka ze Stwórcą pozostaje „cień tajemnicy”, której ludzki intelekt nie zdoła ostatecznie nigdy zgłębić. Bóg na zawsze pozostanie jako nieznany.

Od tego ontycznego i zarazem fundamentalnego faktu nie ma żadnego, doprawdy, żadnego już odwrotu.

${ }^{35}$ M. Olszewski, Komentarz do Kwestii 12. W jaki sposób poznajemy Boga, dz. cyt., s. 606-608.

${ }^{36}$ Zob. Duchowość chrześcijańska. Późne średniowiecze i reformacja, red. J. Raitt, współpr. B. McGinn i J. Meyendoeff, tłum. P. Blumczyński, Kraków 2011, s. 27. 
RAPTURE TO THE «THIRD HEAVEN».

THOMAS AQUINAS ON MYSTICAL EXPERIENCE

Summary

The author of the present paper tackles the questions related to mystical experience in St. Thomas' Aquinas writings. He demonstrates that according to the medieval thinker, assuming the belief of impossibility of experiencing vision of the divine essence in this life, mystical experience of Moses and St. Paul (raptus) should be considered as temporary and transient, that only happens once. Such experience transcends human natural powers since it is God who takes the initiative in rapture. It also remains passive in itself as it occupies only human intellect which is the one to see the divine essence, while the body remains in dormant state. What is more, this experience is limited because someone who experiences rupture is unable to communicate accurately what exactly had happened to him.

Therefore, mystical experience in this life was not of primary importance for St. Thomas. He was more attracted by the direct visual perception of God promised in the Holy Scripture, its implication being that in the supernatural domain the eternal act of knowing God and communion with Him persists. During the visio the object of cognition is more active than its subject. By the infusion of divine light (lumen gloriae) human cognitive abilities are intensified until raptus becomes able to see the divine essence. Naturally, the bestowed grace of seeing God and its intensity depends on experienced intensity of love (caritas) and desire of receiving such grace.

It results from the above that saints do not have the same knowledge of God and do not reach the same level of happiness. The chosen can reach it in accordance with their merits and God's will. However, in the state of salvation the nature of human cognition will not change, since the same human being strives for happiness on earth and reaches it in heaven, realising at the same time his non-self-sufficiency in reaching this state. This problem lies at the core of Thomas' inquiry into visio beatificans.

Keywords: God; contemplation; mysticism; religious experience; Thomas Aquinas; cognition per raptum

Słowa kluczowe: Bóg, kontemplacja, mistycyzm, doświadczenie religijne, Tomasz z Akwinu, poznanie per raptum 


\section{BIBLIOGRAFIA}

Andrzejuk I., Kontemplacja i poznanie «per raptum». Tomaszowe źródła rozumienia istoty doświadczenia mistycznego, „Rocznik Tomistyczny” $2017 \mathrm{nr} 6$, s. 6-67.

Bańka R.A., Josepha Maréchala interpretacja «jasnego widzenia Boga» w doktrynie mistycznej Tomasza z Akwinu, „Folia Philosophica” 2011 nr 29, s. 234-237.

Benedykt XVI, Bóg działa w słabości. Audiencja generalna 13 czerwca 2013, „L'Osservatore Romano" $2012 \mathrm{nr}$ 9-10, https://opoka.org.pl/biblioteka/W/WP/benedykt_xvi/audiencje/ ag_13062012.html [dostęp: 15.06. 2018].

Biela A., Analogia w nauce, Warszawa 1989.

Chenu D.M., St. Thomas d'Aquin et la théologie, Paris 1959 [tłum. polskie: A. Ziernicki, Kraków 1997].

Chenu D.M., Święty Tomasz z Akwinu i teologia, thum. A. Ziernicki, W. Szymona, Kraków 1997.

Chenu D.M., Wstęp do filozofii św. Tomasza z Akwinu, thum. H. Rosnerowa, Kęty 2001.

Duchowość chrześcijańska. Późne średniowiecze i reformacja, red. J. Raitt, współpr. B. McGinn i J. Meyendoeff, thum. P. Blumczyński, Kraków 2011.

Edwards E., Ku poetyce chrześcijańskiej, tłum. M. Szuba, Gdańsk-Pelplin 2017.

Everett L.D., Język. Narzędzie kultury, tłum. Z. Wąchocka, P. Paszkowski, Kraków 2018.

Gaworek S., «Dotknięcie» Boga w doświadczeniu mistycznym wedlug św. Augustyna, „Warszawskie Studia Teologiczne" $2011 \mathrm{nr}$ 2, s. 209-220.

Gilson É., Tomizm. Wprowadzenie do filozofii św. Tomasza z Akwinu, thum. J. Rybałt, Warszawa 1998.

Górnicki M., Antropologia czternastowiecznych mistyków angielskich, Lublin 2018.

Heinzmann R., Filozofia średniowieczna, tłum. P. Domański, Kęty 1999.

Krąpiec A.M., Teoria analogii bytu, Lublin 1993.

Mascall L.E., Istnienie i analogia, tłum. J.W. Zielińska, Warszawa 1961.

McGinn B., Mistycy wczesnochrześcijańscy. Wizje Boga u mistrzów duchowych, thum. E.E. Nowakowska, Kraków 2008.

McGinn B., Fundamenty mistyki. Obecność Boga. Historia mistyki zachodniochrześcijańskiej (do $V$ wieku), tłum. T. Dekert, Kraków 2009.

McGinn B., Mistyczna myśl Mistrza Eckharta, człowieka przed którym Bóg niczego nie skryt, thum. S. Szymański, Kraków 2009.

Moskal P., Tomasza z Akwinu epistemologia przekonań teistycznych, „Łódzkie Studia Teologiczne” $2014 \mathrm{nr}$ 4, s. 5-16.

Nieuwenhove Van R., «Recipientes per contemplationem, tradentes per actionem»: The relations befween the active and contemplative lives according to Thomas Aquinas, „The Thomist” 2017 nr 81, s. 1-30.

Sochoń J., Bóg i język, Warszawa 2000.

Stróżyński M., Kontemplacja Boga u św. Augustyna w perspektywie ewolucji jego filozofii, „Filozofia Chrześcijańska" $2017 \mathrm{nr}$ 14, s. 87-105.

Swieżawski S., Dzieje europejskiej filozofii klasycznej, Warszawa-Wrocław 2000.

Bonawentura, Droga duszy do Boga i inne traktaty, thum. C. Napiórkowski, Poznań 2001.

Thomae Aquinatis, Summa theologiae, Taurini-Romae 1952.

Tomasz z Akwinu, Kwestie dyskutowane o prawdzie, thum. A. Aduszkiewicz, L. Kuczyński, J. Ruszczyński, t. 1-2, Kęty 1998.

Tomasz z Akwinu, Summa contra gentiles. Prawda wiary chrześcijańskiej III, 52, t. II, thum. Z. Włodek, W. Zega, Poznań 2007.

Tomasz z Akwinu, Traktat o Bogu. Summa teologii, kwestie 1-26, thum. i kom. G. Kurylewicz, Z. Nerczuk, M. Olszewski, Kraków 1999.

Turner D., Tomasz z Akwinu. Portret, thum. M. Romanek, Poznań 2017.

Wohlman A., Thomas d'Aquin et Maïmonide un dialogue exemplaire, Paris 1988. 
Zdybicka J.Z., Partycypacja bytu. Próba wyjaśnienia relacji między światem a Bogiem, Lublin 2017.

Jan Sochoń (ur. 1953) - ksiądz, profesor zwyczajny, filozof kultury, poeta, krytyk literacki i eseista; biograf i wydawca pism bł. ks. Jerzego Popiełuszki. Kieruje Katedrą Filozofii Kultury na Uniwersytecie Kardynała Stefana Wyszyńskiego, wykłada także w Wyższym Metropolitalnym Seminarium Duchownym w Warszawie. Stale współpracuje z redakcjami różnych czasopism i Polskim Radiem. Należy do Stowarzyszenia Pisarzy Polskich, PEN Clubu, Polskiego Towarzystwa Tomasza z Akwinu, a także innych gremiów naukowych. Jego utwory przetłumaczono na język angielski, francuski, niemiecki, włoski, rosyjski, czeski, serbski, chorwacki, ukraiński; zostały nadto zamieszczone w kilku zagranicznych antologiach. Otrzymał nagrody: Feniks (2003, 2016), Ogólnopolską Nagrodę Literacką im. Franciszka Karpińskiego, medal Fundacji im. ks. Janusza St. Pasierba (2016), nominowany do nagrody Nike i nagrody Józefa Mackiewicza. Opublikował wiele książek filozoficznych; prac edytorskich oraz tekstów literackich, m.in.: Poszukiwanie literatury (Warszawa 2012), Religia $w$ projekcie postmodernistycznym (Lublin 2012), Jak żyć chrześcijaństwem? (Warszawa 2014), Człowiek $i$ twórczość. Szkice z filozofii kultury (Lublin 2016), Mowa wewnętrzna. Sceny z życia duchowego (Warszawa 2017), tomy wierszy: Wizerunek (Gdańsk 2013), Obrót koła (Pelplin 2014), Sandały i pierścień (Sopot 2015), Półmrok (Paryż 2016), Strzałka czasu (Rzeszów 2017), Klęcznik ze stów. Modlitewnik poetycki (Warszawa 2017), Modlitwa do ciszy. Wybór wierszy (Bydgoszcz 2019), Brewiarz celnika (Sopot 2019). Mieszka w Warszawie. Strona internetowa: jansochon.pl 